\title{
Kajian Terhadap Perkawinan antar Orang Berbeda Agama di Wilayah Hukum Kota Yogyakarta
}

\author{
SETIATI WIDIHASTUTI, SRI HARTINI DAN ENY KUSDARINI \\ FIS, Universitas Negeri Yogyakarta \\ Setiati60widi@gmail.com
}

\begin{abstract}
Abstrak
Penelitian ini bertujuan untuk mengidentifikasi kemungkinan dilangsungkannya perkawinan antar orang berbeda agama di wilayah hukum Kota Yogyakarta, dan mengidentifikasi putusan Hakim Pengadilan Negeri atas permohonan perkawinan antar orang berbeda agama di Catatan Sipil Kota Yogyakarta. Metode yang digunakan adalah deskriptif kualitatif. Wawancara dan dokumentasi dipilih sebagai teknik pengumpulan data. Subyek penelitian ditentukan dengan teknik purposive, yakni dua orang Hakim dan dua pejabat dari Bidang Pencatatan Sipil Kota Yogyakarta. Analisis data dilaksanakan secara induktif, yang tahapannya terdiri dari reduksi data, unitisasi dan kategorisasi data, display data, kesimpulan serta verifikasi. Dalam simpulan kajian ini dapat dikemukakan bahwa: 1) Perlu dispensasi dari Pengadilan Negeri untuk melangsungkan perkawinan beda agama di wilayah hukum kota Yogyakarta. 2) Sikap Hakim PN Yogya atas permohonan perkawinan berbeda agama: (a) menolak memberikan dispensasi, (b) kemungkinan dapat mengabulkan permohonan dispensasi, apabila Hakim berpendapat UU Perkawinan memang tidak mengatur tentang perkawinan beda agama, sehingga terdapat kekosongan hukum.

Kata kunci: perkawinan antar orang berbeda agama, Pengadilan Negeri, Pencatatan Sipil
\end{abstract}

\section{Abstract}

This research aims to identify the possibility of holding marriages between people of different religions in the jurisdiction of the city of Yogyakarta, and identify the District Court Judge's decision on the request for marriages between people of different religions in the Civil Registry of Yogyakarta. The method employed in this research is descriptive qualitative. The interviews and documentations were selected as data collection techniques. The subjects of the research were determined by using purposive techniques, which included two judges and two officials of the Civil Registry Division of Yogyakarta. The data analysis was performed inductively through some stages such as data reduction, data unitization and categorization, data presentation, conclusion and verification. The findings of research include: 1) It should be dispensed from the District Court to hold interfaith marriage in the jurisdiction of the city of Yogyakarta. 2) The attitude of Yogyakarta District Court on the request for a marriage of different religions: (a) refuse to provide dispensation, (b) the possibility of granting dispensation, if the judge believes that the Marriage Law does not regulate interfaith marriage, so that there is a legal vacuum.

Keywords: marriage between people of different religions, the State Court, Civil Registration 


\section{PENDAHULUAN}

Perkawinan antar orang yang berbeda agama masih saja marak dibicarakan, disebabkan karena perkawinan tersebut memang menimbulkan masalah yang tak kunjung usai. Bagi beberapa pasangan, masalah perkawinan orang berbeda agama tersebut memang tidak bisa dihindari, disamping sebagai akibat dari interaksi antar warga masyarakat Indonesia yang majemuk, baik kesukuan, bahasa, terutama agama, juga karena proses legalitas perkawinan agama itu sendiri yang tidak mudah diperoleh.

Sebagai suatu perbuatan hukum, perkawinan pasti membawa akibat hukum, baik yang berkait dengan hak-kewajiban suami istri, keabsahan anak yang lahir dari perkawinan tersebut, kedudukan sebagai ahli waris dan sebagainya. Karena itulah, legalitas atau pengesahan perkawinan merupakan suatu keniscayaan. Mengenai hal-hal yang berkait dengan perkawinan, mulai dari pengertiannya, persyaratan untuk melangsungkan perkawinan baik formil maupun materiil, serta akibat hukum dan pengesahan perkawinan, semua ada diatur dalam Undang-Undang Nomer 1 tahun 1974 tentang Perkawinan, dan peraturan ini berlaku secara nasional sebagai suatu unifikasi.

Pengesahan perkawinan diatur dalam Pasal 2 ayat (1) Undang-Undang Perkawinan yang menyebutkan bahwa perkawinan adalah sah apabila dilakukan menurut hukum masing-masing agama dan kepercayaannya. Dalam penjelasan pasal tersebut dikatakan bahwa tidak ada perkawinan di luar hukum masing-masing agama dan kepercayaannya. Selanjutnya Pasal 2 ayat (2) Undang-Undang Perkawinan menyebutkan bahwa tiap-tiap perkawinan dicatat menurut peraturan perundangan yang berlaku. Dalam Peraturan Pemerintah nomer 9 tahun 1975 yang merupakan peraturan pelaksana dari UndangUndang Perkawinan, petugas pencatat perkawinan bagi mereka yang beragama Islam adalah Kantor Urusan Agama, dan Kantor Catatan Sipil bagi mereka yang beragama selain Islam. Dalam realita yuridis, Pasal 2 ayat (1) dan ayat (2) Undang Undang Perkawinan ter- sebut harus dipenuhi secara akumulatif, dalam arti setelah perkawinan dilangsungkan menurut hukum agamanya, untuk pembuktian perkawinan tersebut harus dicatat oleh lembaga yang berkompeten dan diterbitkan akta nikah/perkawinan yang bersifat otentik. Sebaliknya tidak ada pencatatan perkawinan apabila perkawinan tidak dilangsungkan menurut agamanya.

Apabila persyaratan legalitas perkawinan tidak dipenuhi, secara yuridis formal dianggap "tidak ada perkawinan", sehingga perkawinan tersebut tidak ada akibat hukumnya. Perkawinan yang tidak menimbulkan akibat hukum berpotensi merugikan istri dan anakanak yang lahir dari perkawinan tersebut. Karena istri tidak dapat menuntut haknya sebagai seorang istri, dan anak-anak yang lahir dari perkawinan tersebut hanya mempunyai hubungan keperdataan dengan ibunya saja, dan dalam akta kelahirannya hanya tercantum nama ibu yang melahirkannya saja. Anak yang lahir dari perkawinan yang tidak dicatat, tidak berhak menuntut hak alimentasi kepada ayahnya, serta tidak berhak menjadi ahli waris ayahnya.

Heterogenitas agama yang dipeluk masyarakat Indonesia sangat memungkinkan terjadinya perkawinan antara dua umat yang berlainan agama. Namun pengesahan perkawinannya menimbulkan masalah yang sangat pelik. Sepasang manusia berbeda agama yang menjalin hubungan percintaan harus dihadapkan pada dua pilihan berat: a) menyatukan agama sebelum menyatukan diri dalam perkawinan, b) menggagalkan rencana perkawinan. Yang acapkali terjadi, salah satu pihak mengalah dan berpindah mengikuti agama pasangannya, meskipun "perpindahan agama" tersebut dilakukan sebagai upaya menyiasati ketentuan Pasal 2 ayat (1) Undang-Undang Perkawinan. Setelah perkawinan berlangsung dan dicatat oleh Kantor Catatan Sipil, masing-masing pihak kembali memeluk agama masing-masing. Pasti bukan "pengesahan perkawinan" dengan cara penyelundupan hukum seperti contoh di atas, yang dikehendaki oleh Pasal 2 ayat (1) UU Perkawinan. Berbeda dengan Pasal 40 huruf c Kompilasi Hukum Islam yang dengan 
tegas dan secara eksplisit menyebutkan bahwa "Dilarang melangsungkan pernikahan antara seorang pria dengan seorang wanita yang tidak beragama Islam". Dari ketentuan ini dapat ditegaskan bahwa bahwa Kompilasi Hukum Islam melarang perkawinan beda agama, dan Kantor Urusan Agama tidak mempunyai kompetensi untuk mengesahkan dan mencatat perkawinan diantara dua orang yeng berbeda agama. Dalam Undang -Undang Perkawinan tidak terdapat satu pasal pun yang tegas melarang perkawinan beda agama, tetapi juga tidak ada satu ketentuan pun dalam Undang-Undang Perkawinan tersebut yang memberi peluang untuk pengesahannya. Ketidaktegasan peraturan inilah yang membuat kondisi menjadi serba sulit, dan membingungkan orang berbeda agama yang berkeinginan untuk melangsungkan perkawinan dan mendapatkan legalitas atas perkawinannya tersebut.

Tujuan yang ingin dicapai dalam penelitian ini adalah untuk mengetahui penyelesaian perkawinan antar orang yang berbeda agama di Wilayah Hukum Kota Yogyakarta, mengidentifikasi putusan Hakim Pengadilan Negeri Kota Yogyakarta atas permohonan perkawinan beda agama, dan menggambarkan penyelesaian perkawinan tersebut di Pencatatan Sipil Kota Yogyakarta. Diharapkan hasil penelitian ini dapat memberikan sumbangan pemikiran mengenai konsep-konsep penyelesaian dan pengesahan perkawinan antar umat berbeda agama. Diharapkan selanjutnya sumbangan pemikiran ini dapat dipergunakan oleh Pengadilan Negeri dan Catatan Sipil dalam mengembangkan kebijakan tentang pencarian solusi atas dimungkinkan/tidaknya pengesahan perkawinan beda agama. Hasil penelitian ini juga diharapkan bermanfaat bagi masyarakat untuk lebih memahami tentang keharusan disahkannya semua perkawinan, termasuk permasalahanpermasalahan yang bakal muncul pada saat dua orang yang berbeda agama bermaksud melangsungkan perkawinannya.

\section{METODE}

Penelitian ini merupakan penelitian deskriptif kualitatif yang menggambarkan pe- rilaku Pengadilan Negeri dan Pencatatan Sipil dalam menyelesaikan permasalahan yang terkait dengan perkawinan antar orang berbeda agama.

Subyek penelitian ini ditentukan secara purposive dan sebagai key informan adalah Ketua Pengadilan Negeri Yogya yang selanjutnya menginformasikan nama-nama Hakim berkompeten karena mempunyai pengetahuan dan pengalaman dalam menangani kasus perkawinan beda agama. Subyek penelitian lainnya adalah Kepala Bidang Pencatatan Sipil dan Kepala Seksi Pelayanan Akta Perkawinan dan Perceraian Kota Yogyakarta yang mempunyai kewenangan untuk melakukan pencatatan perkawinan dan menerbitkan alat bukti otentik berupa akta perkawinan. Data primer dalam penelitian ini diperoleh melalui wawancara mendalam dengan para subyek penelitian. Data sekunder diperoleh melalui studi dokumentasi berupa bahanbahan pustaka dan dokumen-dokumen resmi lain, seperti putusan pengadilan, register Pencatatan Sipil dan sebagainya.

Data yang diperoleh dari penelitian ini dianalisis secara induktif. Analisis induktif ini digunakan untuk menilai dan menganalisis data yang telah difokuskan tentang bagaimana Pengadilan Negeri Yogyakarta dan Pencatatatan Sipil Yogyakarta menyelesaikan perkawinan beda agama, kemudian ditarik kesimpulan yang obyektif sesuai dengan fakta. Diawali dari reduksi data yang menghasilkan data yang relevan dan bermakna, dilanjutkan dengan menyusunnya ke dalam unit-unit dan kategori yang sesuai. Selanjutnya dilakukan display atau penyajian data dalam bentuk narasi. Langkah terakhir adalah membuat kesimpulan dan verifikasi agar kesimpulan tidak menyimpang dari permasalahan yang diteliti. Untuk pencermatan kesahihan data pada tahap kegiatan pengumpulan data dan analisis data dilakukan dengan cara sebagai berikut: a) penciptaan rapport yang baik dengan para informan; b) melakukan peer debriefing dengan teman sejawat; dan c) melakukan member check

\section{HASIL DAN PEMBAHASAN}

Tidak terdapat satu pasal pun dalam 
Undang-Undang No. 1 Tahun 1974 yang tegas melarang perkawinan beda agama, tetapi juga tidak ada satu ketentuan yang memberi peluang untuk pengesahannya. Wajar apabila kemudian memunculkan permasalahan, kemana umat berbeda agama akan melangsungkan dan mengesahkan perkawinannya. Mengacu pada Undang-Undang Perkawinan, dapat dikemukakan bahwa pengesahan perkawinan bukan merupakan kewenangan Pengadilan, melainkan merupakan kewenangan sepenuhnya dari lembaga keagamaan dan kantor Catatan Sipil. Namun sejak diundangkannya Undang-Undang Nomer 23 tahun 2006 tentang Administrasi Kependudukan, ada disebutkan keterlibatan Pengadilan, yakni dalam Penjelasan Pasal 35 huruf a yang menyatakan " Perkawinan yang ditetapkan oleh Pengadilan adalah perkawinan yang dilakukan antar umat yang berbeda agama.". Dengan adanya ketentuan tersebut, permasalahan yang terkait dengan perkawinan agama dapat ditangani oleh pengadilan dalam hal ini adalah Pengadilan Negeri.

\section{Penyelesaian Perkawinan Antar Orang Berbeda Agama Di Pengadilan Negeri Yogyakarta}

Menurut seorang hakim PN Yogya, perkawinan antar orang berbeda agama merupakan perkawinan antara dua orang yang tunduk pada hukum agama yang berbeda, sehingga dalam pelaksanaannya sudah pasti muncul kesulitan. Ini dikarenakan hukum positif tidak memberikan peraturan yang tegas, baik tegas melarang atau tegas memperbolehkan. Baik Undang-Undang Perkawinan maupun peraturan pelaksananya sengaja tidak memuat suatu aturanpun yang tegas melarang berlangsungnya perkawinan antar orang berbeda agama. Ini disebabkan karena pada asasnya tidak ada suatu undangundang pun yang dapat melarang seseorang untuk melangsungkan perkawinan, meskipun perkawinan tersebut tidak dimungkinkan oleh agamanya. Hal ini sejalan dengan ketentuan Pasal 28 B ayat (1) UUD 1945 yang menyatakan "setiap orang bebas membentuk keluarga dan melanjutkan keturunan melalui perkawinan yang sah" dan dalam Pasal 28 E ayat (1) UUD 1945 yang menyatakan "setiap orang bebas memeluk agama dan beribadat menurut agamanya........ dst". Dengan kata lain terdapat ruang kebebasan bagi setiap orang untuk melangsungkan perkawinannya serta untuk memeluk agama, sehingga melarang dan menghalangi perkawinan seseorang dengan dalil dan alasan apapun dapat ditafsirkan sebagai satu tindakan yang melanggar hak asasi manusia.

Di kalangan para hakim terdapat perbedaan pandangan terhadap perkawinan antara orang berbeda agama, yakni: a) sebagian hakim yang berpandangan bahwa perkawinan agama tidak diatur dalam UU Perkawinan, sehingga terjadilah rechtsvacuum atau kekosongan hukum, dan b) sebagian hakim lainnya berpendapat bahwa hukumnya sudah jelas, yakni perkawinan antar orang berbeda agama memang tidak dimungkinkan, karena meskipun Undang-Undang Perkawinan tidak tegas melarangnya, tetapi keberadaan Pasal 2 ayat (1) UU Perkawinan menjadi penghalang disahkannya perkawinan tersebut. Perbedaan ini mempengaruhi Hakim dalam memberikan putusan, dalam arti ada kemungkinan hakim akan mengabulkan permohonan para pihak yang mengajukan ijin perkawinan berbeda agama, tapi ada kemungkinan pula hakim akan menolak permohonan tersebut. Perlu dipahami apabila Pengadilan mengabulkan permohonan ijin perkawinan orang berbeda agama, tidak bisa ditafsirkan bahwa Pengadilan telah mengesahkan perkawinan tersebut, melainkan sekedar hanya memenuhi ketentuan Pasal 35 UU No. 23/ 2006 dan Pasal 69 Perpres no. 25 tahun 2008.

Berikut ini adalah satu contoh permohonan perkawinan antar orang berbeda agama yang telah diputus oleh Pengadilan Negeri Yogyakarta dengan Penetapan Pengadilan Nomer 33/Pen.Pdt.P/2009/PN.YK. Garis besar kasus tersebut adalah sebagai berikut: "Sepasang kekasih bermaksud untuk melangsungkan perkawinan di Kantor Urusan Agama (KUA). Permohonan tersebut ditolak oleh KUA karena keduanya berbeda agama, sementara Pasal 40 huruf c Kompilasi Hukum Islam dengan tegas menyebutkan bahwa KUA dilarang melangsungkan perni- 
kahan antara seorang pria dengan seorang wanita yang tidak beragama Islam. Rencana pengesahan perkawinan menemui jalan buntu, karena kedua pihak tetap bertahan pada prinsip dan agama masing-masing. Permohonan pengesahan perkawinan ke Catatan Sipil Yogyakarta juga ditolak, karena kewenangan Pencatan Sipil adalah mencatat perkawinan yang sudah disahkan secara agama, kecuali apabila ada penetapan pengadilan. Selanjutnya Pencatatan Sipil menyarankan para pihak untuk meminta dispensasi ke Pengadilan Negeri.

Hakim Pengadilan Negeri Yogya menyatakan, karena para pihak mengajukan permohonan ijin untuk melangsungkan perkawinan berbeda agama, dengan merujuk pada Pasal 35 UU 23 Tahun 2006 dan Pasal 69 Peraturan Presiden Nomer 25 Tahun 2008, dan dengan mempertimbangkan Pasal 10 ayat (1) UU No. 48 tahun 2009, kondisi pemohon, duduk perkara serta permasalahannya, selanjutnya Pengadilan Negeri Yogyakarta dapat mengeluarkan penetapan. Penetapan Pengadilan tersebut dapat memberikan ijin perkawinan atau menolak permohonan perkawinan tersebut.

\section{Proses Pemeriksaan Permohonan dan Pertimbangan Hakim dalam Memberikan Putusan atas Permohonan Perkawinan Berbeda Agama}

Proses pemeriksaan permohonan melaksanakan perkawinan beda agama ini bersifat sepihak atau ex-parte. Pemeriksaan dilaksanakan oleh Hakim tunggal didampingi oleh seorang panitera pengganti, yang dilaksanakan dengan: 1) mendengar keterangan para pemohon; 2) memeriksa saksi-saksi yang diajukan oleh para pemohon; dan 3) memeriksa bukti-bukti surat. Setelah melakukan pemeriksaan, selanjutnya hakim memberikan putusan atas permohonan ijin perkawinan beda agama ini. Putusan berisi pertimbangan yang memuat fakta dan keadaan yang ditemukan di persidangan beserta alat pembuktian, dan diktum penyelesaian permohonan yang dituangkan dalam bentuk penetapan.

Untuk memperjelas uraian di atas dapat dilihat dalam contoh Penetapan Pengadilan No 33/Pdt.P/2009/PN.Yk. yang pada bagian pertimbangan memuat antara lain hal-hal sebagai berikut:

Menimbang, bahwa Pemohon ........ dst telah mengajukan permohonan yang pada pokoknya sebagai berikut:

- Bahwa Pemohon I (bernama ...................) beragama Katholik telah hamil diluar nikah dengan Pemohon II (bernama ..........)

- Bahwa untuk melaksanakan pernikahan tersebut KUA menyatakan menolak dikarenakan beda agama

- Bahwa keluarga Pemohon I dan II telah melakukan penyelesaian tetapi tidak menemukan titik temu dikarenakan memiliki prinsip sama kuat

- Bahwa dengan melihat kondisi Pemohon I yang hamil semakin besar tetapi tidak ada titik temu untuk penyelesaian dari kedua belah pihak keluarga, maka Pemohon I dan II tetap ingin melaksanakan pernikahan tersebut di Kantor Catatan Sipil dan telah menghadap ke Kantor Catatan Sipil Kotamadya Yogyakarta dan mendapat keterangan supaya mengajukan permohonan ke Pengadilan Negeri Yogyakarta

- Bahwa Pemohon I dan II sangat memerlukan keputusan dari Pengadilan Negeri Yogyakarta

Berhubung dengan hal-hal tersebut di atas, Pemohon I dan II memohon supaya Pengadilan Negeri Yogyakarta memutuskan:

- Menerima dan mengabulkan permohonan Pemohon I dan II

- Menetapkan, memberi ijin dispensasi kepada Pemohon I untuk melakukan pernikahan dengan Pemohon II di hadapan Pejabat pencatatan Sipil Kotamadya Yogyakarta

- Memerintahkan kepada kantor Catatan Sipil Kotamadya Yogyakarta supaya perkawinan Pemohon I dan II dilakukan pencatatan perkawinan 
- Menimbang, bahwa pada hari persidangan yang telah ditentukan Pemohon I dan II menghadap sendiri di persidangan

- Menimbang, bahwa atas pembacaan surat permohonan tersebut, Pemohon I dan II menyatakan tetap pada permohonannya, ... dst

- Menimbang bahwa untuk menguatkan permohonannya, Pemohon mengajukan 8 (delapan) buah foto copy surat bukti berupa........ dst :

- Menimbang, bahwa disamping bukti-bukti surat pemohon juga mengajukan dua (2) orang saksi dst

\section{PERTIMBANGAN HUKUMNYA}

- Menimbang bahwa maksud dari pada permohonan Pemohon I dan II adalah seperti tersebut dimuka;

- Menimbang bahwa permohonan Pemohon diajukan agar Pengadilan Negeri Yogyakarta memberikan ijin pernikahan di Kantor Kependudukan, Keluarga Berencana dan Catatan Sipil

- Menimbang bahwa penetapan tersebut diperlukan karena Pemohon I dan pemohon II berbeda agama

- Menimbang bahwa untuk menguatkan dalil-dalil permohonan Pemohon I dan pemohon II telah mengajukan surat bukti bertanda P.1 sampai dengan P.8 dan 2 (dua) orang saksi di bawah sumpah di persidangan.

- Menimbang bahwa dari bukti-bukti yang diajukan oleh Pemohon ternyata diperoleh faktafakta sebagai berikut:

- Bahwa Pemohon I dan Pemohon II telah pacaran secara serius dan mereka ingin dilanjutkan ke jenjang perkawinan

- Bahwa antara Pemohon I dan pemohon II beda agama dan dalam hal prinsip sama-sama kuat

- Bahwa karena Pemohon I telah hamil maka mereka ingin menyelesaikan permasalahan tersebut dan melaksanakan pernikahan di Kantor Kependudukan, Keluarga Berencana dan Catatan Sipil

- Bahwa Pemohon I dan Pemohon II memerlukan penetapan dari Pengadilan Negeri;

- Menimbang, bahwa dari fakta-fakta terungkap di persidangan tersebut ternyata dapat membuktikan dalil-dalil permohonan Pemohon;

- Menimbang, bahwa dalil permohonan Pemohon I dan Pemohon II telah dapat dibuktikan, ternyata beralasan dan tidak bertentangan dengan hukum, oleh karena itu patut untuk dikabulkan; dst

Sesuai dengan karakteristik dari permohonan atau perkara voluntair, diktumnya bersifat deklarator dalam arti hanya berisi penegasan pernyataan atau deklarasi hukum tentang hal yang dimohonkan. Untuk memperjelas hal tersebut, dapat dilihat dalam contoh Penetapan Pengadilan No 33/ Pdt.P/2009/PN.Yk. yang pada bagian diktumnya yang memuat antara lain hal-hal sebagai berikut:

\section{MENETAPKAN}

- Menerima dan mengabulkan Pemohon I dan Pemohon II

- Menetapkan, memberikan ijin dispensasi kepada Pemohon I untuk melakukan pernikahan dengan Pemohon II di hadapan Pejabat Kantor Kependudukan, Keluarga Berencana dan Catatan Sipil 
- Memerintahkan Kantor Kependudukan, Keluarga Berencana dan Catatan Sipil Kota Yogyakarta supaya perkawinan Pemohon I dan Pemohon II dilakukan pencatatan perkawinan

Atas penetapan pengadilan yang mengabulkan permohonan perkawinan beda agama tersebut, Hakim PN Yogya menyatakan bahwa pemberian dispensasi tersebut tidak dikhawatirkannya akan mempermudah masyarakat untuk melakukan perkawinan beda agama. Menurutnya perkawinan beda agama bukanlah merupakan hukum yang hidup atau living law, karena hanya dilakukan oleh sedikit orang dengan dalih kebebasan. Hukum yang hidup tidak sekedar merupakan perbuatan yang dilakukan secara berulang-ulang, tetapi harus memenuhi rasa keadilan dan dapat diterima oleh masyarakat lingkungannya. Suatu tindakan yang berlawanan dengan rasa keadilan masyarakat, berlawanan dengan hukum dan moral, atau menimbulkan rasa tidak tenang pada anggota masyarakat, tidak dapat dikatakan sebagai hukum yang hidup. Tindakan tersebut lebih tepat dikatakan sebagai penyimpangan, dan karenanya tidak layak mendapatkan legalitas dengan dalih sebagai hukum yang hidup. Kebiasaan sebagai hukum yang hidup tidak semata-mata bisa mendatangkan manfaat demi memenuhi rasa keadilan, tetapi harus bermoral dalam arti tidak bertentangan dengan norma agama. Karena interaksi antara keadilan, hukum yang hidup dan norma keagaamaan merupakan sebuah keniscayaan dalam mewujudkan masyarakat yang dicita-citakan.

\section{Penyelesaian Perkawinan Antar Orang Berbeda Agama di Pencatatan Sipil Kota Yogyakarta}

Perkawinan antar orang berbeda agama merupakan masalah yang sulit penyelesiannya, karena peraturan perundangan tidak memberikan solusi kongkret. Pencegahan adalah tindakan yang senantiasa dilakukan dalam menyikapi permohonan perkawinan antar orang berbeda agama, karena berpotensi melahirkan persoalan-persoalan, antara lain persoalan hukum sebagaimana dapat dicermati di bawah ini:
Karena keabsahan perkawinan merupakan syarat utama untuk melindungi dan mengakui hak anak dan istri, maka perkawinan antar orang berbeda agama yang tidak disahkan, meniadakan hak istri dan anak yang lahir dari perkawinan tersebut.

Perkawinan berbeda agama meniadakan hak kewarisan antara suami istri dan anakanak mereka. Perbedaan agama menggugurkan hak saling mewarisi, karena anak hanya akan mewarisi dari orang tua yang seagama

Rumitnya penentuan Pengadilan tempat menyelesaikan sengketa rumah tangga pasangan yang berbeda agama. Apakah Pengadilan agama berwenang mengadili perkara diantara pihak-pihak yang beragama Islam ataukah Pengadilan Negeri berwenang mengadili perkara pihak-pihak yang bukan muslim. Penyelesaian sengketa menjadi lambat dan berbelit-belit.

Tugas dan kewenangan Pencatatan Sipil adalah tugas administratif, yakni mencatat dan menerbitkan akta otentik yang berfungsi sebagai alat bukti sempurna atas peristiwaperistiwa hukum yang penting, dengan kata lain Pencatatan Sipil tidak mempunyai kewenangan untuk mengesahkan perkawinan. Pencatatan perkawinan bertujuan untuk menjadikan peristiwa perkawinan itu menjadi jelas, baik bagi yang bersangkutan ataupun bagi orang lain dan masyarakat.

Terkait dengan tugas Catatan Sipil untuk mencatat perkawinan, termasuk mencatat perkawinan beda agama yang telah ditetapkan oleh Pengadilan, dapat lebih ditegaskan dengan adanya Surat dari Direktur Jenderal Adiministrasi Kependudukan No. 474.2/708/MD atas nama Menteri Dalam Negeri Republik Indonesia, perihal tentang Pencatatan Perkawinan Beda Agama yang ditujukan kepada Kepala kantor Pendaftaran Penduduk dan Catatan Sipil Kabupaten Muara Enim, yang tembusannya dikirimkan kepada semua Kantor Catatan Sipil di seluruh Indonesia, yang isinya menegaskan bahwa: 
Dengan ditetapkannya UU Nomer 23 Tahun 2006 tentang Administrasi Kependudukan, maka segala kegiatan penyelenggaraan administrasi kependudukan berpedoman pada kebijaksanaan dimaksud, termasuk aspek pencatatan perkawinan oleh Lembaga Pencatatan Sipil. Lembaga Pencatatan Sipil sesuai dengan aturan yang berlaku berfungsi antara lain mencatat segenap peristiwa penting termasuk perkawinan (bukan menikahkan/mengawinkan)

Bagi pencatatan perkawinan beda agama, diatur dalam Pasal 35 yang menyebutkan: "Pencatatan perkawinan sebagaimana dimaksud dalam pasal 34 berlaku pula bagi: a. Perkawinan yang ditetapkan oleh Pengadilan". Sedangkan dalam Penjelasan Pasal 35 huruf a disebutkan: "Perkawinan yang ditetapkan oleh Pengadilan adalah perkawinan yang dilakukan antar umat yang berbeda agama".

Pasal 34 menyebutkan:

Perkawinan yang sah menurut peraturan perundang-undangan wajib dilaporkan oleh penduduk kepada instansi pelaksana ditempat terjadinya perkawinan paling lambat 60 hari sejak tanggal perkawinan

Berdasarkan laporan sebagaimana dimaksud pada ayat (1), Pejabat Pencatatan Sipil mencatat pada Register Akta Perkawinan dan memberikan Kutipan Akta Perkawinan......

Berdasarkan aturan di atas, jelas bahwa perkawinan bagi masyarakat yang berbeda agama dapat dicatatkan setelah mendapat penetapan pengadilan. Sedangkan teknis dalam proses pengadilan dapat dikoordinasikan dengan lembaga pengadilan setempat

\section{Pencatatan Perkawinan Antar Orang Ber- beda Agama Di Pencatatan Sipil Kota Yog- yakarta}

Apabila upaya-upaya pencegahan tidak efektif, dan para pihak tetap berkeras untuk melangsungkan perkawinannya, barulah Catatan Sipil menyarankan para pihak untuk minta "dispensasi" atau ijin melaksanakan perkawinan beda agama ke Pengadilan Negeri, bukan Pengadilan Agama karena dengan merujuk pada Pasal 49 Undang-Undang Nomer 3 tahun 2006, maka Pengadilan Agama tidak berkompeten memberikan dispensasi perkawinan antar orang berbeda agama.

Jikalau para pihak yang berbeda agama tersebut sudah mendapatkan penetapan pengadilan, maka Catatan Sipil akan melaksanakan sesuai dengan amar putusan dari Penetapan Pengadilan. Namun dalam realita penetapan pengadilan yang memberi ijin perkawinan beda agama tersebut telah menimbulkan beberapa permasalahan bagi pihak Catatan Sipil. Pertama, munculnya masalah teknis terkait dengan syarat-syarat yang harus dipenuhi oleh para pihak dan proses pencatatannya, karena tidak ada peraturan atau petunjuk teknis yang dapat dirujuk oleh Catatan Sipil untuk melakukan pencatatan perkawinan beda agama. Kedua, Penetapan Pengadilan (dalam hal ini adalah Penetapan Pengadilan No 33/Pdt.P/2009/ PN.Yk) telah "memperluas" (untuk tidak menggunakan istilah melanggar kewenangan lembaga Pencatatan Sipil). Misalnya, salah satu amar putusan Pengadilan negeri No. No. 33/Pdt.P/2009/PN.Yk berbunyi: "Menetapkan, memberi ijin dispensasi kepada Pemohon I untuk melakukan pernikahan dengan Pemohon II di hadapan Pejabat pencatatan Sipil Kotamadya Yogyakarta". Mengabulkan permohonan tetapi dengan amar putusan seperti tersebut di atas, justru menyulitkan pihak catatan sipil untuk menindaklanjuti. Kata-kata tersebut dapat diartikan sebagai perintah bagi Catatan Sipil untuk satau mengesahkan perkawinan, yang apabila mengacu pada Pasal 2 ayat (1) UU Perkawinan, adalah merupakan kewenangan dari pihak pemuka agama. Sehingga menurut pihak Catatan Sipil, putusan Pengadilan Negeri tersebut tidak sesuai peraturan perundang-undangan yang berlaku. Semestinya Penetapan Pengadilan tersebut memberikan hukumnya, memberikan jalan keluar dan tidak malah memberikan putusan yang menimbulkan banyak penafsiran, yang malah berpotensi membuat Catatan Sipil melanggar ketentuan tentang pengesahan perkawinan. Semestinya putusan tersebut berbunyi "Menetapkan, mengabulkan permohonan dan memerintahkan perkawinan para pemohon diselenggarakan menurut 
agama tertentu". Atau putusan pengadilan tersebut berbunyi " Menetapkan, menolak permohonan pemohon-pemohon", yang artinya putusan hakim tersebut dengan tegas telah menolak permohonan perkawinan beda agama

\section{Pertimbangan Lembaga Pencatatan Sipil melaksanakan Putusan Pengadilan Ten- tang Ijin Perkawinan Antar Orang Berbe- da Agama}

Meskipun penetapan pengadilan yang berisi ijin untuk melangsungkan perkawinan berbeda agama seperti contoh di atas, menimbulkan permasalahan, Catatan Sipil tetap melaksanakannya, dengan pertimbangan antara lain:

Melaksanakan Penetapan Pengadilan dengan mengacu pada Pasal 35 Undang Undang No. 23 Tahun 2006 yang mengatur dan memberi kewenangan kepada catatan sipil untuk mencatat perkawinan yang ditetapkan oleh Pengadilan, yakni perkawinan yang dilakukan antar orang yang berbeda agama.

Catatan Sipil tidak akan mengabaikan Penetapan Pengadilan yang berisi perintah untuk melaksanakan perkawinan antar orang agama tersebut, dengan pertimbangan Pengadilan Negeri merupakan institusi tempat mencari solusi atas semua persoalan hukum. Selain itu Hakim bertanggung jawab atas penetapan dan putusann yang dibuatnya, sehingga dalam memberikan putusannya tentulah sudah didasarkan pada pertimbangan-pertimbangan hukum baik hukum tertulis ataupun tidak tertulis, serta mempertimbangkan nilai-nilai yang hidup dan rasa keadilan masyarakat, sebagaimana diatur dalam Pasal 50 UU no. 48 tahun 2009.

Penetapan Pengadilan yang berisi ijin atau dispensasi kepada para pihak untuk melangsungkan perkawinan antar orang berbeda agama tersebut merupakan akta otentik. Ini relevan dengan yang pendapay Yahya Harahap (2011:41), bahwa putusan pengadilan mempunyai kekuatan otentik, berarti sesuai dengan Pasal 1870 KUH Perdata, pada diri putusan tersebut melekat nilai ketentuan pembuktian yang sempurna dan mengikat.

Karena salah satu amar putusan Penga- dilan Negeri tersebut (dalam hal ini adalah Penetapan Pengadilan No 33/Pdt.P/2009/ PN.Yk) tidak sesuai peraturan perundangundangan yang berlaku, pihak Catatan Sipil hanya melaksanakan sebagian dari Penetapan Pengadilan tersebut, yakni tidak melangsungkan perkawinan, tetapi melakukan pencatatan tanpa disertai bukti pengesahan agama. Meskipun hal ini berarti persyaratan untuk sahnya perkawinan tidak dapat dipenuhi secara akumulatif, dan Catatan Sipil telah bertindak dengan mengabaikan Pasal 2 ayat (1) UU Perkawinan

\section{SIMPULAN}

Dipenghujung kajian ini dapat dikemukakan simpulan sebagai berikut:

Secara normatif perkawinan antar orang berbeda agama tidak bisa disahkan karena adanya dua persyaratan yang harus dipenuhi secara akumulatif, yakni: ketentuan Pasal 2 ayat (1) dan ayat (2) UU Perkawinan. Namun di wilayah hukum kota Yogyakarta, perkawinan antar orang berbeda agama masih mungkin untuk dilangsungkan, meskipun dalam pelaksanaannya tidaklah mudah, dan diperlukan adanya pemberian ijin atau dispensasi dari Pengadilan Negeri

Pengadilan tidak mempunyai kompetensi apapun terkait dengan pengesahan perkawinan, tetapi dengan adanya Pasal 35 dan penjelasan pasal 35 UU Nomer 23 tahun 2006 tentang Administrasi Kependudukan yang menyatakan "Catatan Sipil mencatat perkawinan yang ditetapkan oleh Pengadilan, yakni perkawinan antar umat yang berbeda agama", dapatlah diartikan Pengadilan mempunyai kewenangan terkait dengan penyelesaian perkawinan beda agama. Sehingga mengacu pada ketentuan di atas, dan sepanjang disarankan oleh Pencatatan Sipil, maka Pengadilan Negeri Yogya akan memeriksa dan memutus permohonan perkawinan beda agama.

Terkait dengan permohonan perkawinan beda agama, ada dua pandangan hakim di PN Yogya, yakni: a) Hakim yang berpendapat bahwa perkawinan antar umat beda agama tidak dimungkinkan, karena hukumnya sudah 
jelas, yakni pengesahannya terhalang oleh Pasal 2 ayat (1) UU Perkawinan akan MENOLAK permohonan tersebut, sedangkan b) hakim yang berpendapat perkawinan beda agama tidak diatur dalam UU Perkawinan, sehingga terdapat kekosongan hukum, yang apabila dibiarkan akan berdampak negatif dalam hidup bermasyarakat dan beragama, berupa penyelundupan nilai-nilai sosial, agama dan hukum positif, kemungkinan akan mengabulkan permohonan dan memberikan ijin perkawinan antar mereka yang berbeda agama.

Apabila sudah diperoleh penetapan pengadilan, Catatan Sipil akan melaksanakan sesuai dengan amar putusan. Pencatatan dilakukan pihak Catatan Sipil dengan MENGABAIKAN ketentuan Pasal 2 ayat (1) UndangUndang Perkawinan, antara lain dengan cara melakukan pencoretan terhadap pernyataan yang menyebutkan pengesahan perkawinan secara agama dan menggantinya dengan pernyataan " TELAH DITETAPKAN OLEH PENGADILAN NEGERI YOGYA DENGAN PENETAPAN PENGADILAN NO

Untuk mengatasi berbagai masalah tersebut, sudah saatnya UU Perkawinan direvisi, dan secara tegas melarang perkawinan antar orang berbeda agama, karena walaupun pengadilan memberikan dispensasi, tetapi karena pelaksanaan pencatatannya terpaksa dilakukan Catatan Sipil dengan mengabaikan Pasal 2 ayat (1) UUPerkawinan, menyebabkan perkawinan beda agama tidak lebih dari samen leven (hidup bersama) yang dicatat.

\section{UCAPAN TERIMA KASIH}

Atas terlaksananya penelitian ini, kami mengucapkan terimakasih kepada :

Dekan FIS UNY, Prof. Dr. Ajat Sudrajat, M.Ag. yang telah memberikan fasilitas berupa ijin pelaksanaan penelitian.

Bapak/ibu dosen Jurusan PKNH, FIS, UNY yang telah memberikan masukan untuk kesempurnaan penelitian ini.

\section{DAFTAR PUSTAKA}

Badan Penelitian dan Pengembangan Agama. 2000. Perkawinan Antar Agama, Poligami dan Pelanggaran Undang-Undang Perkawinan. Departemen Agama. Jakarta

Moleong, Lexy J. 2004. Metodologi Penelitian Kualitatif. Bandung: Remaja Rosdakarya.

Harahap, M Yahya. 2011. Hukum Acara Perdata . Jakarta. Sinar Grafika.

Syahrani, Riduan. 2006, Seluk Beluk dan Asasasas Hukum Perdata. Bandung: Alumn.

Sanapiah Faisal. 1990. Penelitian Kualitatif Dasar-dasar dan Aplikasi. Malang: YA3. 